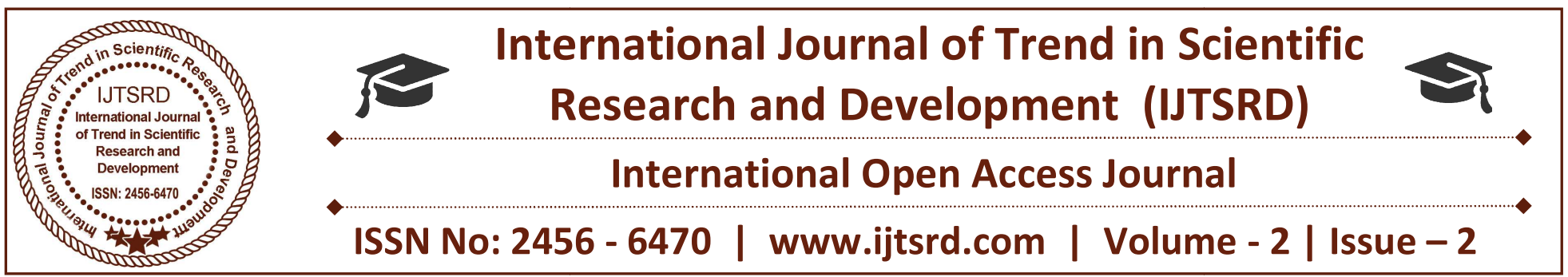

\title{
Dr B R Ambedkar as a Visionary Educationist
}

\author{
SK Habib \\ Asst. Teacher, Dasbaga Basu Kacharibati Primary School, Uluberia East \\ Howrah, West Bengal, India
}

\begin{abstract}
The prime objective of the present paper is to study the educational philosophy of Dr.Ambedkar. Further the paper analyses the implications of his philosophy in the present scenario. His philosophy has great idea for practical fulfillment and these ideas have the relevance to modern society. Ambedkar believed that education is a movement. If it does not fulfill its objectives, it is useless. True education cradles humanity, generates sources of livelihood, imparts wisdom and imbues us with egalitarianism. His credentials as a thinker were established through his articles, books and magazines, and also the newspapers that he published. Among his own books were The Problem of Rupee, Provincial Finance in British India, Annihilation of Caste and who were the Shudras? Ambedkar believed that education was the most important means of raising the people's standard of living. His slogan was "Educate, unite, struggle".Human dignity and self-respect were central to his social philosophy. He wanted to use education to establish justice, equality, fraternity, freedom and fearlessness in society. He wanted to replace the birthbased society with a value-based one. It goes without saying that these moral values can be promoted only through education. In the end I will conclude by sharing my personal views on the particular subject.
\end{abstract}

Keywords: Dr. B. R. Ambedkar, Visionary Educationist, Great Philosopher, The Indian Constitution

\section{INTRODUCTION}

The prime objective of the present paper is to study the educational philosophy of Dr.Ambedkar. Further the paper analyses the implications of his philosophy

in the present scenario. His philosophy has great idea for practical fulfillment and these ideas have the relevance to modern society. In the end I will conclude by sharing my personal views on the particular subject.

The educational progress that our nation is witnessing today is due to the remarkable contribution of great educationists like Swami Dyanand Saraswati, Swami Vivekananda, Sri Aurobindo, Mahatma Gandhi, Raja Ram Mohan Roy, Madan Mohan Malviya and surely Dr. B.R.Ambedkar was one such great philosopher

His ideas and educational doctrines have successfully demonstrated through the age, sex through the best educational system of the world and his cherished ideals have already been incorporated into the educational system of modern India.

Dr.B.R. Ambedkar stressed on the idea of social development based on self respect, equality and fraternity. His ideas are well known through his great work "The Indian Constitution" which provides safeguards to each individual in the society under article 12 to 24 .He greatly stressed on the education of the untouchables. He provided for the safeguard of the untouchables under article 17 of the constitution. He established the Bahishkrit Hitkarini Sabha which had amongst its objectives the opening of hostels and classrooms for them. He emphasized on the role of women education in the society. According to him women education can change her home and also encourage a child for education. He worked for the upliftment of the backward and the depressed classes. To overcome the financial problem of the backward 
and oppressed classes he stressed the necessity of scholarship in educational institutions. He said that education was necessary to shake off the mental sluggishness and satisfaction with their existing plight. He put all his effort to guarantee the education without discrimination to all citizens of independent India.

\section{Dr.B.R.Ambedkar's Views on Education}

According to Dr.B.R. Ambedkar to change the society of its backwardness it is very necessary to spread education. Education eradicates the bias of people which results on to minimize the exploitation, domination, of those people who try to take the benefit of the so called illiterate people:

"If the people get knowledge through education then they can face the problems created by the people who dominate them. Education reforms opinions, it tries to remove the walls built among the people. The biggest gift that is given by the education is that it creates self confidence among us which is considered as the first stage of our development."[1]

Ambedkar furthermore explains that the work without knowledge is blind and futile. He was of the opinion that when people do work without education it is just like to waste human power. He sometimes asserts if a person leading is illiterate he will definitely carry us towards darkness just like that it is the position of our leaders. For him if a leader is not educated and does not encourage the spread of education then he can drag the whole society towards deterioration. Thus what Ambedkar wants to say is that education is the vital element for the development of society and human beings. Ambedkar was much farsighted and he talked not only about the primary education but also the higher education. For him the spread of primary education to higher education begets the versatile leaders who carry us towards the betterment. While comparing life with competition, Ambedkar in one of his speeches addresses that:

"The people don"t sustain in the struggle of life until they get educated. Since that they get caught in the clutches of social problems such as insult, suppression and desecration. So it is the duty of the existing government to accelerate by providing education." [2]

In the days of Ambedkar the educational condition of untouchables was very critical. He was of the opining that:
"The untouchables were deliberately being kept away by Brahmans and other castes. It was just because they drive the education system. They just tried to behave with untouchables as inferior.'[3]

It resulted to take an effective action against government. Further he tries to make changes in education system after the worse experience with untouchables. According to Ambedkar:

"Education is a weapon of creation of mental and educational development, weapon of eradication of social slavery of economic development of political freedom.'[4]

While emphasizing on the need of education he puts forth the demand of law of compulsory education. He knew that the problem of primary education is the problem of nation. $\mathrm{He}$ in the conference of Mahabaleshwar held on May 31, 1929 addressed that:

"The problem of the spread of primary education is the most dominating one. In the present days these countries who bear the maximum Dalit illiterates don ${ }^{e t}$ sustain in the competition of life. It will take more time if the spread of primary education is dependent on the interest of common people. So it needs to implement a compulsory Act of primary education, so it needs to implement a compulsory Act of primary education.'[5]

So what Ambedkar wished through this speech was that there should not only be Acts but it should also be compulsorily implemented. He knew that compulsory education requires a lot of expenditure and if this opportunity is given in the hands of local selfgovernment then it faces the problem of money which results in the failure of Act. But actually the position is that our education system is caught in the hands of those who don 't know about it. So, to remove this it needs the free and compulsory education. According to Ambedkar to solve the problem of expenditure the centre and the state government should come forward and make a compromise. Ambedkar further opines that those citizens who can afford to pay the fee should be allowed to pay but those who are economically very weak to pay the fee should be exempted from it. Ambedkar Continues by saying that it should be the moral responsibility of the government to ensure that education shouldn ${ }^{\text {eet }}$ be very costly. Even the poor should get free education so that the country should gain its achievement very soon. While supporting this point Ambedkar says that, "there should not be separate education for boys and 
girls."[6] For him education doesn ${ }^{e e} t$ differentiate the sex.

\section{Relevance of Dr.B.R.Ambedkar's Thoughts in the Present Scenario}

After sixty three years of independence the government realized the importance of thoughts of Ambedkar and wanted to bring them into reality. If a country wants to sustain their existence in modern period then it needs an effective educational system. When this educational system becomes effective, it gives proper shape to the scientific and technical development. If the base of primary education is weak, then what is the use of higher education?

There should not be value of saying India as a developing country. Hence to escape from these obstacles central government declared „Right to Education $^{\text {ee }}$ as a fundamental right from April 1, 2010. On the occasion of this day the ,dream ${ }^{\text {ee }}$ of Ambedkar came into reality when the prime minister of India declared that the right to education is one of the fundamental rights.

When we study Right to Education Act $2009^{\circ e}$, we come across with many similarities of Ambedkar"s thoughts with the provisions in it. While addressing to nation, Dr. Manmohan Singh said that "Indian government is pleading to educate every child in India."[7] This "Right to Free Education Act 2009" has been implemented since April 1, 2010(No.35 of 2009).’[8]

There are some provisions of this Act which shows its roots in the thoughts of Dr. Ambedkar:

- The Act makes free and compulsory education to all children of India in the six to fourteenyears group.

- No child should be held or expelled or required to pass board examination until the completion of elementary education (up to eighth class).

- It provides $25 \%$ reservation for economically disadvantaged communities in all private and minatory schools. It also prohibits all unrecognized schools form practice and makes provisions for no donation or capitation fees and no interview or parents for admission.

- This Act is applied to all of India except Jammu and Kashmir.
- There should be combine education both for boys and girls.

- The financial burden will be shared between state government and central government on the basis of "Sarva Shikshan Abhiyan". In April 2010 the central government agreed to share the funding for implementing the law in the ratio of $65 \%$ to $35 \%$ between the centre and the state. A ratio of $90 \%$ to $10 \%$ for north eastern states.

Thus, from the provisions made in " Right to Education Act" it can be proved that the thoughts of Ambedkar before the independence are brought in reality as in ,Compulsory and Free education Act $^{\text {ee }}$ in India to bring children in the flow of education. It helped nation to reduce the traditional monopoly and slavery of ruling class. Ambedkar had already suggested that right to education should be compulsory and while implementing this government and central government have to make compromise of revenue among them. The most important matter that should be discussed is that the law did $25 \%$ reservation for economically disadvantaged communities to be expelled from dominating class in education and combine education for boys and girls. Moreover, the provisions in this will definitely release the Dalits from the dominance of certain classes. Whatever Dr. Ambedkar had thought came into reality with the successful implementation of this Act.

The very concept of "night school education" was also the influence of Ambedkar"s thought during the last two decades of twentieth century. Apart from these Dr. Ambedkar highlights on higher education system. According to him,

"The education in university should be society oriented. It should be scientific and away from prejudice, it should not be limited with the benefit of certain classes in society. He also adds that the aim of education is not only to teach thermos but it should enable to teach them how to develop the personality, to increase their intellectual capacities..."[9]

In another speech Ambedkar says that,

"In the present system university has given very less powers to control the colleges. For him in spite of power of discipline, rejection of approval of college, university needs more powers. If these 
powers are endowed to university then the colleges will be treated neatly under the supervision of university...’[10]

However, when we see the statute of university we come across the various powers endowed to university. By the result of this we have management council, Senate, Academic council and various faculties of university.

\section{Conclusion}

Precisely speaking, Ambedkar's educational thoughts seem to be the milestones for present situation. Whatever changes Dr. Ambedkar had proposed through his thoughts about the education system in primary and higher are in the form of law in modern era.

Ambedkar was true in saying when he declared that his contemporary education system was faulty and was at the bottom of degradation of Indian civilization. Whatever it may be, but the decisions taken by central government about the education system have the roots in the thoughts of Dr.Ambedkar. Moreover it can be said that under the obligation of Dr. Ambedkar India is going to become a world power through intellectual human resources which are brought only through education. Not only this but also the decisions taken by University Grants Commission about university and research in it shall be undoubtedly the products of Ambedkares s thoughts in this era.

\section{Notes and References}

1) Anjanikar Bhagwan. Thoughts from Siddharth College papers, Vidya Upasak Dr. Babasaheb Ambedkar (trans), Nanded, Nirmal Publication, 1999, page 23.

2) Dr. Babasaheb Ambedkar's Writings and Speeches, (trans) vol.19, Dr. Babasaheb Ambedkares Biography means publishing committee, Mumbai, 2005, page 283.

3) Ibid, page 146. 4) Dr. Lulekar Pralhad. Anant Pailuncha Samajik Yoddha, (trans) Pune, Sayas publication , 2011, page 77 .

4) Ibid, page 77 .

5) Ibid, page 80 .

6) Speech of Dr. Dr. Manmohan Singh delivered on August 1, 2010.
7) The Gazette of India, New Delhi, August 2009 , part 2.

8) Dr.Babasaheb Ambedkar's Speeches and Thoughts, ,(trans) ed. Dr. Dahat Dhanraj, vol.2, page 142-143.

9) Ibid, page 145 .

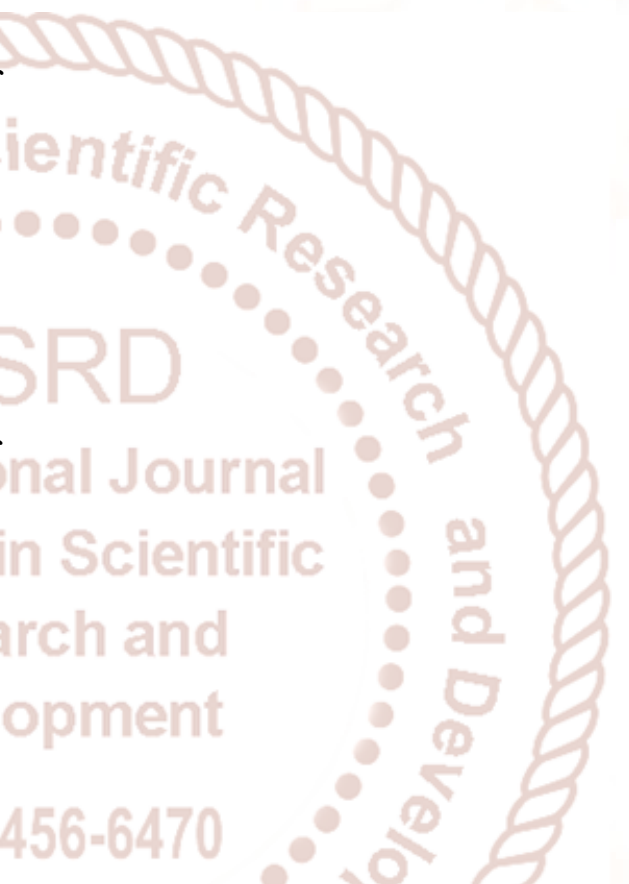

